J. Amer. Soc. Hort. ScI. 120(1):21-24. 1995

\title{
Effect of Primocane Suppression Date on 'Marion' Trailing Blackberry. I. Yield Components
}

\author{
Neil C. Bell ${ }^{1}$, Bernadine C. Strik ${ }^{2}$, and Lloyd W. M artin ${ }^{3}$ \\ Department of Horticulture, Oregon State University, Corvallis, OR 97331-7304 \\ Additional index words. Rubus spp., pruning, training
}

\begin{abstract}
Primocanes of 'Marion' trailing blackberry plants (Rubus spp.) were suppressed by cutting them off at ground level in either late April, May, June, or July 1991 and 1992. A control was included in which primocanes were not cut. Four canes per plant were trained in either August or February, with all other canes being removed and measured. Yield data were collected in 1992 and 1993, after which yield components were measured. Cane diameter was greatest for unsuppressed plants and declined with later primocane removal date. Cane length was greatest for unsuppressed and April-suppressed plants. Internode length decreased and main cane percent budbreak increased with later suppression date. Cane number and total main cane length per plant were increased in April-, May-, and June-suppressed plants in 1992 and for April- and June-suppressed plants in 1993. Consequently, yield of April-suppressed plants exceeded that of unsuppressed plants in 1992. Yield of April-, May-, and June-suppressed plants exceeded that of unsuppressed plants in 1993. August-trained plants yielded $46 \%$ more than February-trained plants, primarily because of higher percent budbreak on main canes. August-trained plants also produced longer canes with more nodes and a greater number of fruit per main cane lateral.
\end{abstract}

About $98 \%$ of the blackberry hectarage in Oregon is planted with cultivars having a trailing growth habit. The most important of these is 'Marion', which accounts for over 50\% of the blackberry hectarage in the state and continues to be widely planted (Strik, 1992). Although 'Marion' is a vigorous cultivar with excellent fruit quality, yields in many growers' fields are often disappointingly low. Alternative systems of primocane suppression are of interest as a means to increase yield and stabilize production.

Many studies have shown that yield of red raspberry can be significantly increased by removing the first flush, and subsequent flushes, of primocanes from plants (Freeman and Daubeny, 1986; Waister et al., 1977; Williamson et al., 1979). Yield increases as a result of this practice have also been demonstrated in trailing blackberry (Sheets and Kangas, 1972). The timing and frequency of primocane removal also has a major impact on the productivity of red raspberry in subsequent years (Crandall et al., 1980; Freeman and Daubeny, 1986). If primocanes are not suppressed, then potential yield increases are forfeited, and the longercanes become a nuisance for training and harvesting. Removing canes too late can cause a swift and severe decline in vigor (Lawson and Wiseman, 1983).

The present study was undertaken to examine the effect of different primocane suppression dates and training time on the productivity of individual canes and whole plants of 'Marion' blackberry.

\section{Materials and Methods}

A 7-year-old planting of 'Marion' blackberry on a Latourell loam soil at the North Willamette Research and Extension Center

Received for publication 18 Apr. 1994. Accepted for publication 21 July 1994 Oregon State Univ. Agricultural Experiment Station Technical Paper 10469. From the MS thesis of N.C. Bell. The cost of publishing this paper was defrayed in part by the payment of page charges Under postal regulation\, this paper therefore must be hereby marked advertisement solely to indicate this fact.

${ }^{1}$ Research assistant, North Willamette Research and Extension Center.

${ }^{2}$ Associate professor.

${ }^{3}$ Professor. Present address: Department Head, Dept. of Horticulture and Forestry, Univ. of Arkansas, 316 Plant Science Bldg., Fayetteville AR 72701. in Aurora, Ore., was used. Plants were spaced at $2.4 \mathrm{~m}$ within rows spaced $3.1 \mathrm{~m}$ apart. The trellis consisted of posts with two horizontal wires at 1.2 and $1.5 \mathrm{~m}$. Weed control, irrigation, and fertilization followed standard commercial practice.

Experimental design. Five primocane suppression treatments were randomly assigned to two-plant plots. One plant in each plot was trained in August, the other in February. The treatments were arranged in a split-plot, with primocane suppression date as the main effect and training time as the subplot effect, with five replications. Since July-suppressed plants could not be summertrained because of insufficient cane growth at that time, this suppression treatment was excluded from the analysis of training time effects.

Primocane suppression. The primocane suppression treatments involved cutting all primocane growth at ground level with pruning shears (Lawson and Wiseman, 1983). All primocanes on both plants in each plot were removed on a single occasion in either late April, May, June, or July 1991 and 1992. A control treatment was included in which primocanes were not cut. These treatments will be referred to as April-, May-, June-, and July-suppressed, or unsuppressed, respectively. All primocanes produced by the plants following the suppression treatment were allowed to grow for the rest of the season.

Training time. Canes of the summer-trained plants were wrapped on the wires in late August. The winter-trained treatment involved leaving canes in a single bundle on the ground through the winter, and training in late February. Four canes were randomlyselected from each plant and wrapped in standard commercial style around both wires of the trellis. Canes were left at their full length per standard commercial practice. The remaining canes on each plant were removed and total cane number and main cane and branch cane length were measured. These data were added to the main cane and branch cane data from the four canes remaining on the plant to get total cane production per plant.

Yield components. Total yield and fruit size data were collected from each plant. After harvest, cane diameter $(30 \mathrm{~cm}$ from the base) and total main cane length were measured on each cane. To facilitate yield component measurement, canes were then divided into three equal-length sections. The variables measured on each section were number of nodes, number of fruitful laterals or branch 
canes, lateral length, and number of fruit per lateral. The same variables, with the exception of cane diameter, were measured separately on each branch cane. Data were used to calculate percent fruitful budbreak, average lateral length, and number of fruit per lateral.

Yield and fruit size data were considered on a per-plant basis. Yield per meter of main cane was calculated by dividing yield per plant by the main cane length of the four canes left on the plant. Potential yield per plant was calculated by multiplying the total main cane production per plant by yield per meter of cane.

Data analysis. Data were analysed using general linear model procedures (SAS Institute, 1988) for a split-plot design. Mean separation for suppression date was done by the Waller-Duncan $\mathrm{k}$ ratio test. Fisher's LSD was used for comparison of the effect of training time.

\section{Results}

Suppression date. There was a significant interaction of year and suppression date for most variables, but no suppression date by training time interaction. Cane diameter and main cane length generally decreased with later primocane suppression date (Table 1). However, all suppression treatments had a higher number of canes per plant than control plants in 1992, while April- and Junesuppressed plants had more canes in 1993. Consequently, total main cane length per plant was increased for April-, May-, and June-suppressed plants compared to the control in 1992 and for April- and June-suppressed plants in 1993 (Table 1). Branch cane production was greatest on unsuppressed plants and declined the later the suppression date. June- and July-suppressed plants tended to produce few or no branch canes. In contrast, almost $50 \%$ of the total yield of unsuppressed plants was borne on branch canes in 1992 (data not shown).

Internode length on main canes decreased with later suppression date, while percent budbreak increased (Table 1). There were no consistent differences among treatments in either main cane or branch cane lateral length (data not shown). Differences in number of fruit per main cane lateral were not significant in 1992, but Mayand June-suppressed plants produced the highest number of fruit per lateral in 1993 and July-suppressed plants the fewest (Table 1). Fruit weight was lower for June- and July-suppressed plants (data not shown).

Yield per meter of cane was highest for unsuppressed and Maysuppressed plants in 1992, but cold injury substantially reduced productivity of unsuppressed and April-suppressed plants in 1993. May- and June-suppressed plants had the highest productivity in 1993 (Table 1). Because of a much larger total cane length per plant, potential yields were highest for April-suppressed plants in 1992. June-suppressed plants had the highest potential yield in 1993, followed by April- and May-suppressed plants. July-suppressed plants had the lowest potential yields in both years (Table 1).

Training time. There was no significant year by training time interaction. August-trained plants had longer canes with more nodes than February-trained plants (Table 2). Percent budbreak on main canes and the number of fruit per main cane lateral were significantly higher for August-trained plants. Yield per meter of cane and potential yield of August-trained plants were higher than those of February-trained plants (Table 2). Training time had only a minimal effect on fruit weight and no significant effect on lateral length (data not shown).

Table 1. Effect of primocane suppression date on yield components of 'Marion' blackberry in 1992 and 1993.

\begin{tabular}{|c|c|c|c|c|c|c|c|c|c|c|c|}
\hline \multirow[b]{2}{*}{$\begin{array}{l}\text { Suppression } \\
\text { date }\end{array}$} & \multicolumn{9}{|c|}{ Main cane } & \multirow[b]{2}{*}{$\begin{array}{l}\text { Potential } \\
\text { yield/plant } \\
(\mathrm{kg})\end{array}$} & \multirow{2}{*}{$\begin{array}{c}\text { Branch } \\
\text { cane } \\
\text { length/ } \\
\text { plant } \\
\text { (m) }\end{array}$} \\
\hline & $\begin{array}{l}\text { No./ } \\
\text { plant }\end{array}$ & $\begin{array}{l}\text { Diam } \\
(\mathrm{mm})\end{array}$ & $\begin{array}{l}\text { Length } \\
\text { (m) }\end{array}$ & $\begin{array}{c}\text { No. } \\
\text { nodes }\end{array}$ & $\begin{array}{c}\text { Internode } \\
\text { length } \\
(\mathrm{mm})\end{array}$ & $\begin{array}{l}\text { Length/ } \\
\text { plant } \\
(\mathrm{m})\end{array}$ & $\begin{array}{c}\text { Budbreak } \\
(\%)\end{array}$ & $\begin{array}{c}\text { No. } \\
\text { fruit/ } \\
\text { lateral }\end{array}$ & $\begin{array}{c}\text { Yield/m } \\
(\mathrm{kg})\end{array}$ & & \\
\hline \multicolumn{12}{|l|}{1992} \\
\hline Control & $10.3 C^{2}$ & $10.7 \mathrm{~A}$ & $4.6 \mathrm{~A}$ & $73 \mathrm{~A}$ & $63 \mathrm{~A}$ & $37.7 \mathrm{C}$ & $36 \mathrm{D}$ & 6.2 & $0.43 \mathrm{a}$ & $15.5 \mathrm{~b}$ & $52.7 \mathrm{~A}$ \\
\hline April & $19.4 \mathrm{AB}$ & $7.5 \mathrm{~B}$ & $4.4 \mathrm{~A}$ & $74 \mathrm{~A}$ & $60 \mathrm{AB}$ & $70.9 \mathrm{~A}$ & $40 \mathrm{CD}$ & 5.8 & $0.31 \mathrm{bc}$ & $20.9 \mathrm{a}$ & $41.6 \mathrm{~B}$ \\
\hline May & $18.8 \mathrm{AB}$ & $7.0 \mathrm{~B}$ & $3.7 \mathrm{~B}$ & $66 \mathrm{AB}$ & $56 \mathrm{~B}$ & $56.6 \mathrm{~B}$ & $41 \mathrm{BC}$ & 6.3 & $0.33 \mathrm{ab}$ & $18.5 \mathrm{ab}$ & $27.8 \mathrm{C}$ \\
\hline Iune & $20.0 \mathrm{~A}$ & $6.4 \mathrm{C}$ & $3.1 \mathrm{C}$ & $61 \mathrm{~B}$ & $51 \mathrm{C}$ & $50.2 \mathrm{~B}$ & $49 \mathrm{~A}$ & 6.1 & $0.31 b c$ & $15.3 \mathrm{~b}$ & $8.5 \mathrm{D}$ \\
\hline July & $15.8 \mathrm{~B}$ & $5.6 \mathrm{D}$ & $2.1 \mathrm{D}$ & $42 \mathrm{C}$ & $50 \mathrm{C}$ & $31.3 \mathrm{C}$ & $44 \mathrm{AB}$ & 4.8 & $0.21 \mathrm{c}$ & $6.6 \mathrm{c}$ & $0.1 \mathrm{E}$ \\
\hline \multicolumn{12}{|l|}{1993} \\
\hline Control & $10.7 \mathrm{C}$ & $11.0 \mathrm{~A}$ & $4.0 \mathrm{AB}$ & $59 \mathrm{AB}$ & $70 \mathrm{~A}$ & $33.7 \mathrm{C}$ & $28 \mathrm{~B}$ & $4.7 \mathrm{BC}$ & $0.24 \mathrm{~b}$ & $6.7 \mathrm{C}$ & $67.0 \mathrm{~A}$ \\
\hline April & $18.5 \mathrm{~A}$ & $9.5 \mathrm{~B}$ & $4.7 \mathrm{~A}$ & $71 \mathrm{~A}$ & $67 \mathrm{~B}$ & $62.9 \mathrm{~A}$ & $30 \mathrm{~B}$ & $5.0 \mathrm{~B}$ & $0.16 \mathrm{c}$ & $10.7 \mathrm{~B}$ & $46.8 \mathrm{~B}$ \\
\hline May & $12.1 \mathrm{C}$ & $9.2 \mathrm{~B}$ & $3.4 \mathrm{BC}$ & $56 \mathrm{~B}$ & $61 \mathrm{C}$ & $40.8 \mathrm{BC}$ & $43 \mathrm{~A}$ & $6.4 \mathrm{~A}$ & $0.31 \mathrm{a}$ & $11.9 \mathrm{~B}$ & $19.8 \mathrm{C}$ \\
\hline June & $17.5 \mathrm{AB}$ & $7.6 \mathrm{C}$ & $2.8 \mathrm{C}$ & $48 \mathrm{~B}$ & $57 \mathrm{D}$ & $50.7 \mathrm{AB}$ & $50 \mathrm{~A}$ & $6.1 \mathrm{~A}$ & $0.33 \mathrm{a}$ & $16.6 \mathrm{~A}$ & $2.6 \mathrm{D}$ \\
\hline July & $13.5 \mathrm{BC}$ & $6.5 \mathrm{D}$ & $1.1 \mathrm{D}$ & $23 \mathrm{C}$ & $49 \mathrm{E}$ & $16.6 \mathrm{D}$ & $46 \mathrm{~A}$ & $3.8 \mathrm{C}$ & $0.24 \mathrm{~b}$ & $4.1 \mathrm{C}$ & $0.0 \mathrm{D}$ \\
\hline
\end{tabular}

${ }^{2}$ Mean separation in columns within year by Waller-Duncan test, $P=0.05$ (lower case letters) or 0.01 (upper case letters).

Table 2. Effect of training time on yield components of 'Marion' blackberry.

\begin{tabular}{lcccccccc}
\hline \hline & \multicolumn{9}{c}{ Main cane } & \multicolumn{2}{c}{$\begin{array}{c}\text { Potential } \\
\text { Training }\end{array}$} & $\begin{array}{c}\text { Length } \\
\text { time }\end{array}$ & $\begin{array}{c}\text { No. } \\
\text { nodes }\end{array}$ & $\begin{array}{c}\text { Length/plant } \\
(\mathrm{m})\end{array}$ & $\begin{array}{c}\text { Budbreak } \\
(\%)\end{array}$ & $\begin{array}{c}\text { No. fruit/ } \\
\text { lateral }\end{array}$ & $\begin{array}{c}\text { Fruit size } \\
(\mathrm{g})\end{array}$ & $\begin{array}{c}\text { Yield/m } \\
\mathrm{cane}(\mathrm{kg} / \mathrm{m})\end{array}$ & $\begin{array}{c}\text { yield/plant } \\
(\mathrm{kg})\end{array}$ \\
\hline August & 4.2 & 69 & 52.3 & 46 & 6.5 & 5.0 & 0.35 & 17.2 \\
February & 3.5 & 58 & 48.5 & 33 & 5.1 & 5.2 & 0.25 & 11.8 \\
Significance & $* *$ & $* *$ & NS & $* *$ & $* *$ & $*$ & $* *$ \\
\hline
\end{tabular}

${ }^{2}$ Mean separation by Fisher's LSD.

Ns,***Nonsignificant or significant at $P=0.05$ or 0.01 , respectively. 


\section{Discussion}

Our results of the suppression treatments on trailing blackberry provide an interesting comparison to the effects of chemical and mechanical primocane suppression on red raspberry. A single chemical primocane suppression spray in red raspberry has no effect on cane number and total cane length per plant, while two chemical sprays tend to reduce both over time (Crandall et al., 1980). However, in 'Marion' blackberry, primocane suppression tended to increase the number of canes per plant and, if the Julysuppressed plants are excluded, the total main cane length per plant. The effect of removal date on cane length was consistent with the results of Lawson and Wiseman (1983) who found that removal of primocanes of red raspberry before they were $60 \mathrm{~cm}$ long had no effect on final length, but that later suppression drastically reduced cane length.

Primocane suppression also has contrasting effects on cane productivity in red raspberry and 'Marion' blackberry. Primocane suppression in red raspberry reduces subsequent cane production but increases productivity per unit length of cane (Lawson and Wiseman, 1983; Nehrbas and Pritts, 1988). In our study of 'Marion' blackberry, primocane-suppressed plants produced more canes whose individual productivity was generally reduced. This pattern was altered in 1993, but we feel this was the result of winter injury in February to unsuppressed and April-suppressed plants. Latersuppressed plants were unaffected by this cold weather, illustrating their greater hardiness (Bell et al., 1994).

The principal reason for the decrease in per-cane productivity was the progressive decrease in branch cane production with later dates of primocane suppression. However, the increased number of canes was more than sufficient, in three of the four suppression treatments, to compensate for the significant decline in yield per cane. It is evident that branch canes are as important to the productivity of 'Marion' trailing blackberry as they are to other Rubus genotypes like purple raspberry (Gundersheim and Pritts, 1991) and erect blackberry (Moore and Skirvin, 1990). Most of this branch cane production occurred in the basal section of canes.

The increase in percent budbreak with later suppression date was surprising given that in raspberry, large-diameter canes show greater reproductive vigor than thinner canes (Crandall et al., 1974). In 'Marion', however, large sections of cane on unsuppressed plants were often found to be barren of laterals or branch canes. Failure of these buds, particularly in years such as 1992 when winter injury was not a problem, was perhaps the result of withincane competition between branch canes and main cane buds. This situation may be analogous to the development of multiple fruiting laterals at individual nodes in red raspberry, which tends to be accompanied by a reduced overall percentage of fruitful nodes (Jennings, 1979). That these nonfruitful nodes may only be latent was shown in 1993, when winter injury reduced percent budbreak on middle and terminal parts of unsuppressed and April-suppressed canes. Apparently, in response, percent budbreak was doubled on basal sections compared to 1992. It is apparent that 'Marion' canes possess a substantial ability to compensate for lost buds by increased production at remaining nodes. This capability has been demonstrated in red raspberry (Braun and Garth, 1984; Waister and Barritt, 1980).

A reduction in pest and disease problems with later dates of suppression may also have increased percent budbreak. Several studies have shown that problems with pests and cane disease in red raspberry are reduced by primocane suppression treatments (Freeman and Daubeny, 1986; Williamson et al., 1979). Although an objective rating was not done in this study, suppression ap- peared to reduce cane disease, particularly purple blotch [Septocyta ruborum (Lib.) Petr].

The differences in yield by training time confirm the findings of Sheets et al. (1972). That August-trained plants yielded $46 \%$ more than February-trained in this study was primarily the result of increased main cane length, higher percent budbreak, and an increased number of fruit per main cane lateral. August-trained plants tend to have longer canes because cane growth continues on the trellis, while February-trained plants remain on the ground and tip-root in late summer. The increase in main cane budbreak and fruit number per main cane lateral with August-training may be the result of two factors. With canes on the wire in late summer as compared to being left on the ground during the winter, there is a probable improvement in light exposure and a less favorable environment for the development of fungal disease and pests. Dale (1986) suggested that the number of fruit per lateral in red raspberry could be increased in a favorable environment and Swartz et al. (1984) attributed yield increases of V-trellised raspberries to the improved light exposure of primocanes. Studies on grapes have shown that variation in yield from node to node along the vine can be partly explained by differences in illumination of the leaf subtending the node the previous year (Smart et al., 1982).

The results suggest that primocane removal between late April and June would increase yield of trailing blackberry while providing several other important benefits: the shorter canes and reduction of branch cane growth would simplify training and possibly allow closer spacing of plants within the row, further enhancing the yield per unit area; fewer sprays for cane disease control would be required; and later dates of suppression may increase primocane hardiness (Table 1; Bell et al., 1994). Cane suppression treatments were repeated in 1993 and informal observation suggests that plant vigor for most treatments has been maintained for the 3 years of the experiment. However, suppression in late July may be too devigorizing over a period of several years. If plants were grown in an alternate-year production system (Strik, 1992), primocane suppression would be done only every second year, and problems with loss of vigor could possibly be avoided. Training plants in August is definitely preferable to February because of the yield advantage. August-training is a commercial practice, although previous industry surveys have found August-trained plants more susceptible to winter injury than February-trained plants (Bell et al., 1992).

\section{Literature Cited}

Bell, N., E. Nelson, B. Strik, and L. Martin. 1992. Assessment of winter injury to berry crops in Oregon, 1991. Agr. Expt. Sta. Spec. Rpt. 902, Oregon State Univ.

Bell, N.C., B.C. Strik, and L.W. Martin. 1994. Effect of primocane suppression date on 'Marion' trailing blackberry. II. Cold hardiness. J. Amer. Soc. Hort. Sci. 120:25-27.

Braun, J.W. and J.K.L. Garth. 1984. Intracane yield compensation in the red raspberry. J. Amer. Soc. Hort. Sci. 109:526-530.

Crandall, P.C., D.F. Allmendinger, J.D. Chamberlain, and K.A. Biderbost. 1974. Influence of cane number and diameter, irrigation, and carbohydrate reserves on the fruit number of red raspberries. J. Amer. Soc. Hort. Sci. 99:524-526.

Crandall, P.C., J.D. Chamberlain, and J.K.L. Garth. 1980. The effects of chemical primocane suppression on growth, yield, and chemical composition of red raspberries. J. Amer. Soc. Hort. Sci. 105:194-196.

Dale, A. 1986. Some effects of the environment on red raspberry cultivars. Acta Hort. 183:155-161.

Freeman, J.A. and H.A. Daubeny. 1986. Effect of chemical removal of primocanes on several raspberry cultivars. Acta Hort. 183:215-222.

Gundersheim, N.A. and M.P. Pritts. 1991. Pruning practices affect yield, 
yield components, and their distribution in 'Royalty' purple raspberry. J. Amer. Soc. Hort. Sci. 116:390-395.

Jennings, D.L. 1979. The occurrence of multiple fruiting laterals at single nodes of raspberry canes. New Phytol. 82:365-374.

Lawson, H.M. and J.S. Wiseman. 1983. Techniques for the control of cane vigour in red raspberry in Scotland: Effects of timing and frequency of cane removal treatments on growth and yield in cv Glen Clova. J. Hort. Sci. 58:247-260.

Moore, J.N. and R.M. Skirvin. 1990. Blackberry management, p. 214244. In: G.J. Galletta and D.G. Himelrick (eds.). Small fruit crop management. Prentice Hall, Englewood Cliffs, N.J.

Nehrbas, S.R. and M.P. Pritts. 1988. Effect of pruning system on yield components of two summer-bearing raspberry cultivars. J. Amer. Soc. Hort. Soc. 113:314-321.

SAS Institute Inc. 1988. SAS/STAT user's guide. release 6.03. SAS Inst., Cary, N.C.

Sheets, W.A., R.M. Bullock, and R. Garren, Jr. 1972. Effects of plant density, training, and pruning on blackberry yield. J. Amer. Soc. Hort. Sci. 97:262-264.
Sheets, W.A. and K.F. Kangas. 1972. Chemical pruning of blackberries with dinoseb. Proc. Oregon Hort. Soc. 63: 118-119.

Smart, R.E., N.J. Shaulis, and E.R. Lemon. 1982. The effect of Concord vineyard microclimate on yield. II. The interrelations between microclimate and yield expression. Amer. J. Enol. Viticult. 33:109-116.

Strik, B.C. 1992. Blackberry cultivars and production trends in the Pacific Northwest. Fruit Var. J. 46:202-206.

Swartz, H.J., S.E. Gray, L.W. Douglass, E. Dumer, C.S. Walsh, and G.J. Galletta. 1984. The effect of a divided canopy trellis design on thornless blackberry. HortScience 19533-535.

Waister, P.D. and B.H. Barritt. 1980. Compensation in fruit numbers following loss of lateral buds in the red raspberry. Hort. Res. 20:25-31. Waister, P.D., M.R. Cormack, and W.A. Sheets. 1977. Competition between fruiting and vegetative phases in the red raspberry. J. Hort. Sci. 52:75-85.

Williamson, B., H.M. Lawson, J.A.T. Woodford, A.J. Hargreaves, J.S. Wiseman, and S.C. Gordon. 1979. Vigour control, an integrated approach to cane, pest and disease management in red raspberry (Rubus idaeus). Ann. Applied Biol. 92:359-368. 